\title{
IMPACT OF ANTIHELMINTHIC TREATMENT ON INFECTION BY Ascaris lumbricoides, Trichuris trichiura AND HOOKWORMS IN COVAS, A RURAL COMMUNITY OF PERNAMBUCO, BRAZIL
}

Luciana Carvalho ZANI(1), Tereza Cristina FAVRE(1), Otávio Sarmento PIERI(1) \& Constança Simões BARBOSA(2)

\begin{abstract}
SUMMARY
This work aims to evaluate the impact of drug treatment on infection by Ascaris lumbricoides (Al), Trichuris trichiura (Tt) and hookworms (Hook) in a rural community from the sugar-cane zone of Pernambuco, Brazil. Four parasitological surveys were carried out from March 2001 to March 2002. Individual diagnosis was based on eight slides (four by the Kato-Katz method and four by the Hoffman method) per survey. Infected subjects were assigned to two groups for treatment with either albendazole $(\mathrm{n}=62)$ or mebendazole $(\mathrm{n}=57)$. Prevalence of infection fell significantly $(\mathrm{p}<0.05)$ one month after treatment: Al (from $47.7 \%$ to $6.6 \%)$; $\mathbf{T t}$ (from $45.7 \%$ to $31.8 \%$ ) and Hook (from $47.7 \%$ to $24.5 \%$ ). One year after treatment, infections by Tt and Hook remained significantly below precontrol levels. A substantial decrease in single-infection cases and multiple infections was found. Egg-negative rate was significant for Al $(94.0 \%)$, Hook $(68.3 \%)$ but not for Tt $(45.5 \%)$, and did not differ significantly between subjects treated with mebendazole or albendazole. Egg counts fell significantly in the individuals remaining positive for Tt. It is recommended that antihelminthic treatment should be selective and given at yearly intervals preferably with albendazole, due to its cost-effectiveness.
\end{abstract}

KEYWORDS: Mebendazole; Albendazole; Geohelminthiasis, Rural Area.

\section{INTRODUCTION}

Among geohelminths, Ascaris lumbricoides, Trichuris trichiura and hookworms are the most prevalent and widespread ${ }^{8}$. In Brazil, it is estimated that 2.9 to 4.3 million people suffer from multiple geohelminthic infections ${ }^{6}$. However, very few studies have evaluated the real situation of geohelminthiasis in this Country ${ }^{24,33}$. Research has been restricted to the description of outpatients from health institutions and schoolchildren ${ }^{12,34}$, or children under five years of age in an urban setting ${ }^{13,20,27}$. No emphasis has been given to interventive studies on geohelminths in rural areas, despite a recommendation by $\mathrm{WHO}^{36}$ that control of intestinal helminthiasis and intestinal schistosomiasis should be combined, and regardless of the fact that both diseases frequently occur together ${ }^{6}$.

Due to lack of resources, geohelminthiasis control has been restricted to the treatment of the infected population with drugs that affect the egg counts directly, thus reducing morbidity levels. Two benzimidazoles are currently recommended (albendazole and mebendazole) for use in control programs $^{21}$. However, there have been no comparative field studies aiming to evaluate which of the two drugs is more appropriate for rural communities.

The present study evaluates the impact of selective treatment with mebendazole or albendazole on infection by A. lumbricoides, $T$. trichiura and hookworms, by comparing infection indices prior to and after chemotherapeutic intervention in a sugar-cane farming village in the state of Pernambuco, Brazil.

\section{MATERIAL AND METHODS}

Approval by the Ethics Committee: The present study is part of a research project entitled "Prevalence survey of intestinal helminthiases in rural communities of Pernambuco, submitted to chemotherapeutic control" under the coordination of Tereza Cristina Favre, approved by the Ethics Committee of Fiocruz (CEP/Fiocruz), in June 2000 (protocol no. 112/ 00 ), the final report of which was also approved by the CEP/Fiocruz.

Characterization of the study area: Covas (35' 7' 33' 'W; $8^{\circ} 4^{\prime} 14^{\prime \prime}$ $S)$ is a rural community endemic for schistosomiasis, located in the municipality of São Lourenço da Mata, Pernambuco Brazil, 12 km southwest from the municipal center. The last local parasitological survey, carried out by the National Foundation of Health in 1996, detected a prevalence rate of $43 \%$ for Schistosoma mansoni ${ }^{11}$. Covas was selected for the study due to ecological features favorable not only to the transmission of schistosomiasis, but also of geohelminthiasis. Epidemiological, topographical, climatic and hydrographical information on the site was collected in December 2000.

Figure 1 shows a schematic representation of the main elements from Covas. It has 52 houses, spread over a rugged terrain, with sandy clay soil, 


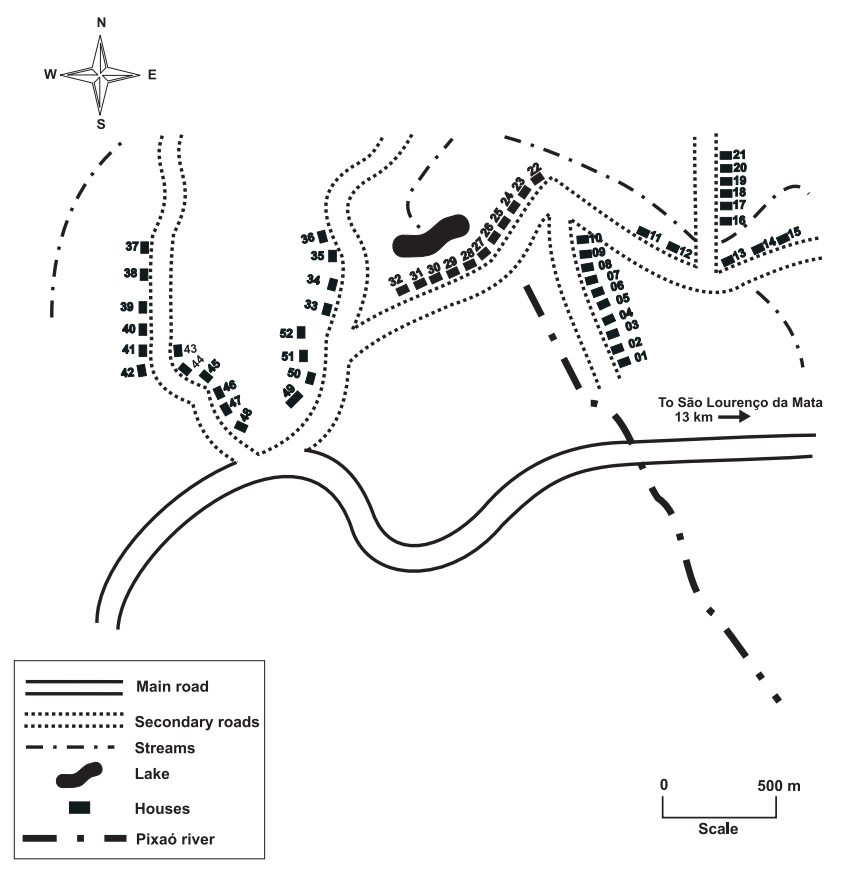

Fig. 1 - Schematic representation of the main hydrographic and topographic aspects, as well as housing distribution from Covas (35 $7^{\circ} 33^{\prime \prime}$ W; $8^{\circ} 4^{\prime} 14^{\prime}$ ' S), in the municipality of São Lourenço da Mata, Pernambuco state, Brazil.

used mainly for sugarcane plantation. The main source of water is the Pixaó River that cuts the village from Northwest to Southeast. The heads of four seasonal streams and a small pond are located in the area and they all flow into the Duas Unas Dam, located about $3 \mathrm{~km}$ to the North. The climate is tropical, rainy with dry summers (Köppen Classification), with average temperatures varying from $24{ }^{\circ} \mathrm{C}$ to $27^{\circ} \mathrm{C}$. The annual average rainfall is $1,250 \mathrm{~mm}$ and the rainy season stretches from March to August. Between January and December 2001, total rainfall, estimated by the Institute of Meteorology (Inmet), was 1,430 mm. From that total, 1,040 $\mathrm{mm}-72.7 \%$ of rainfall - occurred during the rainy season.

By December 2000, the population of 250 inhabitants occupied 44 of the 52 houses and was distributed according to age group as follows: $14.8 \%$ (0-6 years), $22.0 \%$ (7-14 years), $18.4 \%$ (15-19 years), $16.0 \%$ (20-29 years), $16.8 \%$ (30-49 years) and $12.0 \%$ (50-83 years). The main professional occupation was sugarcane planting and cutting that accounted for a family income of 1 to 2 minimum wages. Thirty-three (75.0\%) of the 44 houses occupied by families were constructed from bricks, with earthen floors. Seventeen $(38.6 \%)$ houses had no sanitary facilities and the remaining $27(61.4 \%)$ had sewage systems in very precarious conditions. Remains of food and dejecta from 20 (45.5\%) houses were thrown in their yards. The only sources of water were streams and artesian wells. Thirty-five families $(79.5 \%)$ raised small animals (dogs, cats, chickens and pigeons) that circulated freely in the houses. The community had a municipal school, (first to fourth grades) for children aged $7-14$ years.

Social, demographic, sanitary and behavioral survey: In December 2000, homes were numbered and residents were registered. A standard questionnaire ${ }^{37}$ was answered by heads of the households in order to obtain sociodemographical, financial, sanitary and behavioral information relevant to the epidemiology of schistosomiasis and geohelminthiasis. The same questionnaire was distributed in December 2001 to detect possible changes among relevant variables over the study period.

Parasitological surveys and treatment of infected cases: Four coproscopic surveys were carried out (March, May and October 2001 and March 2002). In each survey, subjects were sampled twice at intervals of 3 to 4 days. Each sample was processed both by the Kato-Katz method ${ }^{18}$ (two slides per subject) and by Hoffmann's spontaneous sedimentation method $^{15}$, by which two slides, with a standardized aliquot of $80 \mu \mathrm{l}$ of sediment, were prepared for each subject from $4 \mathrm{~g}$ of feces. Therefore, the parasitological diagnosis for each subject, in each survey, was made from a total of eight slides and subjects were considered positive whenever there were eggs on at least one of these. Estimates for the number of eggs per gram of feces (epg) for each subject per survey were made by adding the number of eggs found on each Kato-Katz slide, multiplying this sum by 24 and dividing the result by the number of slides (four).

Treatment of the positive subjects started in April 2001, immediately after the results of the survey of March 2001 and repeated, twenty days later, in order to account for the larvae in transit in the host at the time of the first treatment ${ }^{36}$. Pregnant or lactating women, children under the age of two, and subjects with intense infection involving expulsion of worms through the mouth and feces, did not receive any medication. In such cases, the results of the parasitological tests were issued with a recommendation or directions to seek help from the local health-care center. Two groups of positive subjects were constituted by matching all those eligible for treatment by sex, age and infection category (single, double or triple-infection), and by taking into consideration the species of geohelminth. Each group was randomly assigned to treatment with one or the other antihelminthic drug. The treatment was administered by a health agent in the presence of the research team. Mebendazole (100 mg: LAQFA) was administered twice a day over three consecutive days, and albendazole (400 mg: Neoquímica), was administered in a single dose. The subjects positive for S. mansoni were treated in April 2001 with praziquantel (60 mg/kg: Far-Manguinhos/Fiocruz), a week after the treatment for geohelminthiasis.

The first survey enabled us to identify the subjects tested positive for each geohelminthiasis, as well as to estimate the prevalence of infection and the intensity of infection prior to treatment. The survey of May 2001 enabled an estimation of the egg-negative rate, the reduction of egg counts, as well as to detect any subjects remaining positive after treatment with each drug. The surveys of October 2001 and March 2002 made it possible to estimate rates of re-infection and to follow the infection dynamics after treatment.

Indices of infection: The following indices were used according to MONTRESOR et al. ${ }^{21}$ :

a) Prevalence of infection - percentage of subjects tested positive for each geohelminth species, in relation to the number of subjects examined. This was estimated for the whole population and for a group of 151 fully complying subjects, who participated in all surveys and, whenever positive, were medicated (follow-up cohort).

b) Cumulative prevalence of infection - prevalence of infection with at least one geohelminth species. 
c) Prevalence of multiple infections - prevalence of infection with at least two geohelminth species. This was estimated by taking as a basis a group of 119 subjects tested positive that received medication and participated in at least the Hoffmann and/or Kato-Katz tests performed in the surveys of March and May 2001 (infected cohort).

d) Intensity of infection - geometric mean (GM) of the number of eggs per gram of feces, calculated as antilog $\left[\Sigma \log _{10}(\mathrm{epg}+1) / \mathrm{n}\right]-1$, where $\Sigma \log _{10}(\mathrm{epg}+1)$ is the sum of the logarithm of each individual epg to which one egg is added to permit calculation of the logarithm in case epg $=0$. It was estimated only for subjects included in the follow-up cohort $(\mathrm{n}=151)$, and tested by the Kato-Katz method.

e) Egg-negative rate - percentage of subjects tested positive (March 2001) who had been treated (April 2001) and who became negative one month after treatment (May 2001). This rate was estimated by taking as a basis the infected cohort $(n=119)$.

f) Rate of egg reduction - calculated as [1 - (GM after treatment/GM before treatment)] x 100. It was only estimated for cases remaining positive after treatment as detected by the Kato-Katz method.

g) Rate of reinfection - percentage of positive subjects who became negative one month after treatment (May 2001), but who were found to be positive again in the surveys of October 2001 or March 2002.

The cases of single and multiple infection involving S. mansoni were excluded from both the follow-up and infected cohorts. Thus, the subjects participating in these cohorts were not concomitantly infected with $S$. mansoni and geohelminth species and, consequently, did not receive any treatment for schistosomiasis.

Statistical analysis of data: The Sign test ${ }^{26}$ was employed to assess significant differences in the prevalence of infection for each helminth species between the survey prior to treatment (March 2001) and each of the three subsequent surveys, as well as and in the egg-negative rate for each helminth between March 2001 and May 2001. Matched $t-$ test $^{29}$ was used to evaluate significant differences in the intensity of infection among positive subjects in the follow-up cohort grouped by age and by geohelminth species, between the survey prior to treatment (March 2001) and each of the three subsequent surveys. Contingency tables ${ }^{26}$ were used to evaluate significant differences in egg-negative rate between subjects treated with mebendazole and those receiving albendazole, as well as in reinfection rate between the two following periods: June - October 2001 and November - March 2002.

\section{RESULTS}

The participation of the population in the stool tests was $91.3 \%$ (200/ 219 persons) in March 2001, 95.7\% (199/208) in May 2001, 95.6\% (196/205) in October 2001 and 84.5\% (174/206) in March 2002. Compliance to treatment was $86.2 \%$ (119/138). The remaining 19 subjects, not receive any medication, due to contraindication. Sixty-two were treated with albendazole and 57 with mebendazole.

Indices of infection in the population: Cumulative prevalence of geohelminthiases was $69.0 \%$ prior to treatment, dropping 21.3 percentage points (pp) one month after the treatment. Although this prevalence remained below the initial level in all post-treatment surveys, it progressively increased, reaching $54.1 \%$, in October 2001 and $57.5 \%$, in March 2002. The initial prevalence of infection (March 2001) for each geohelminth was above $44.0 \%$, but fell one month after treatment. Six months after treatment there was an increase in prevalence of each geohelminthiasis and, as a consequence, in cumulative prevalence. Eleven months after treatment, prevalence of all three geohelminthiases remained below pre-treatment levels (Table 1).

Indices of infection in the follow-up cohort $(n=151)$ : Prevalence of A. lumbricoides in this cohort fell significantly one month after treatment (Table 1). Nevertheless, six and eleven months after treatment, it increased up to the point of not differing statistically from the one registered in March 2001. Prevalence of T. trichiura and hookworms were also significantly reduced one month after treatment, remaining below the initial level even six and eleven months after treatment.

Prevalence of A. lumbricoides (Fig. 2A), prior to treatment was above $39.0 \%$ in all age groups, except for the group with oldest subjects (5082 years). One month after treatment, there was a significant decrease of prevalence in all four groups ranging from 7 to 49 years. However, in the subsequent surveys, prevalence was only kept significantly below the pre-treatment level in October 2001 in the age group of 20-29 years. As for intensity (Fig. 3A), before treatment it was concentrated in the younger groups (0-6 years and 7-14 years). With the treatment, the egg counts fell significantly in all age groups, except for the 50-82 years

Table 1

Prevalence of infection by Ascaris lumbricoides, Trichuris trichiura and hookworms in the population as well as in the follow-up cohort from Covas, prior to (March 2001) and at subsequent surveys after treatment of the positive individuals.

\begin{tabular}{|c|c|c|c|c|c|c|c|c|}
\hline \multirow[t]{2}{*}{ Group } & \multirow{2}{*}{$\begin{array}{l}\text { Parasitological } \\
\text { surveys }\end{array}$} & \multirow{2}{*}{$\begin{array}{c}\mathrm{N}^{\mathrm{o}} \\
\text { examined }\end{array}$} & \multicolumn{2}{|c|}{ A. lumbricoides } & \multicolumn{2}{|c|}{ T. trichiura } & \multicolumn{2}{|c|}{ Hookworms } \\
\hline & & & Positive & $\%$ & Positive & $\%$ & Positive & $\%$ \\
\hline \multirow[t]{4}{*}{ Population } & March/2001 & 200 & 98 & 49.0 & 89 & 44.5 & 94 & 47.0 \\
\hline & May/2001 & 199 & 21 & 10.6 & 65 & 32.7 & 53 & 26.6 \\
\hline & October/2001 & 196 & 74 & 37.8 & 72 & 36.7 & 67 & 34.2 \\
\hline & $\mathrm{March} / / 2002$ & 174 & 78 & 44.8 & 61 & 35.1 & 51 & 29.3 \\
\hline \multirow[t]{4}{*}{ Cohort } & March/2001 & 151 & 72 & 47.7 & 69 & 45.7 & 72 & 47.7 \\
\hline & May/2001 & 151 & 10 & $6.6^{*}$ & 48 & $31.8 *$ & 37 & $24.5 *$ \\
\hline & October//2001 & 151 & 57 & $37.7^{\mathrm{NS}}$ & 51 & $33.8 *$ & 51 & $33.8 *$ \\
\hline & $\mathrm{March} / 2002$ & 151 & 68 & $45.0^{\mathrm{NS}}$ & 50 & $33.1 *$ & 39 & $25.8 *$ \\
\hline
\end{tabular}

*, significant $(\mathrm{p}<0.05)$; NS, not significant $(\mathrm{p} \geq 0.05)$. 
group, whose level was already near zero. In the subsequent surveys, however, prevalence increased substantially, surpassing significantly the pre-treatment level in the 15-19 years age group. The impact of treatment on intensity of infection in the cohort as a whole was only significant in May 2001.

Prevalence of T. trichiura (Fig. 2B) before treatment ranged from $25.0 \%$, in the group with the oldest subjects (50-82 years), to $65.9 \%$, in the 7-14 year-old group. Significant decrease in prevalence after treatment in all age groups was not detected. As for intensity (Fig. 3B), the age group with highest egg counts before treatment was 7-14 years. This was the only group that presented a significantly reduced egg count after treatment. However, the impact of treatment on intensity of infection in the cohort as a whole remained significant from May 2001 until the last survey.
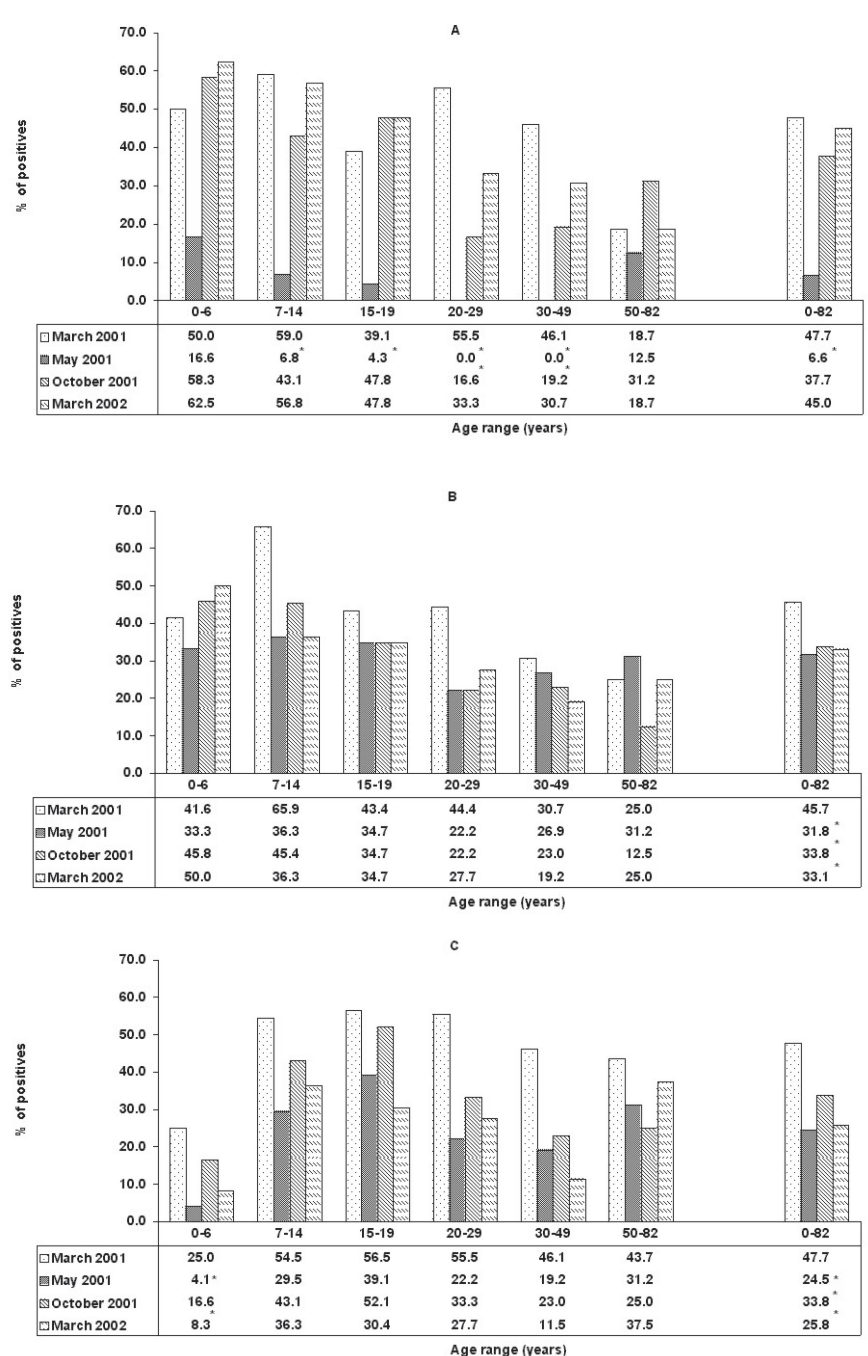

Fig. 2 - Prevalence of infection (\% of positive) by Ascaris lumbricoides (2A), Trichuris trichiura (2B) and hookworms (2C) in the follow-up cohort from Covas, by age range, prior to (March 2001) and at subsequent surveys after treatment. The asterisks indicate significant differences $(\mathrm{p}<0.05)$ between the pre-treatment survey and each subsequent survey.
Prevalence of hookworms (Fig. 2C) before treatment was above $43.0 \%$ in all age groups, except for the youngest one (0-6 years). The highest values of prevalence were found in the 7-29 year-old range. The treatment only had a significant impact on prevalence in the 0-6 years group. As for intensity (Fig. 3C), before treatment the highest rate was found in the 7-14 year-old group. After treatment, the egg count did not drop significantly only in the 0-6 and 50-82 year-old groups, where it was already minimal. In the subsequent surveys, intensity remained significantly below the pre-treatment level in the 15-19 and 30-49 yearold groups. In the cohort as a whole, the impact of treatment on intensity of infection remained significant until the last survey.

Indices of infection in the infected cohort $(n=119)$ : The assignment of 119 positive-tested subjects for treatment with mebendazole or albendazole taking into account the main intervening
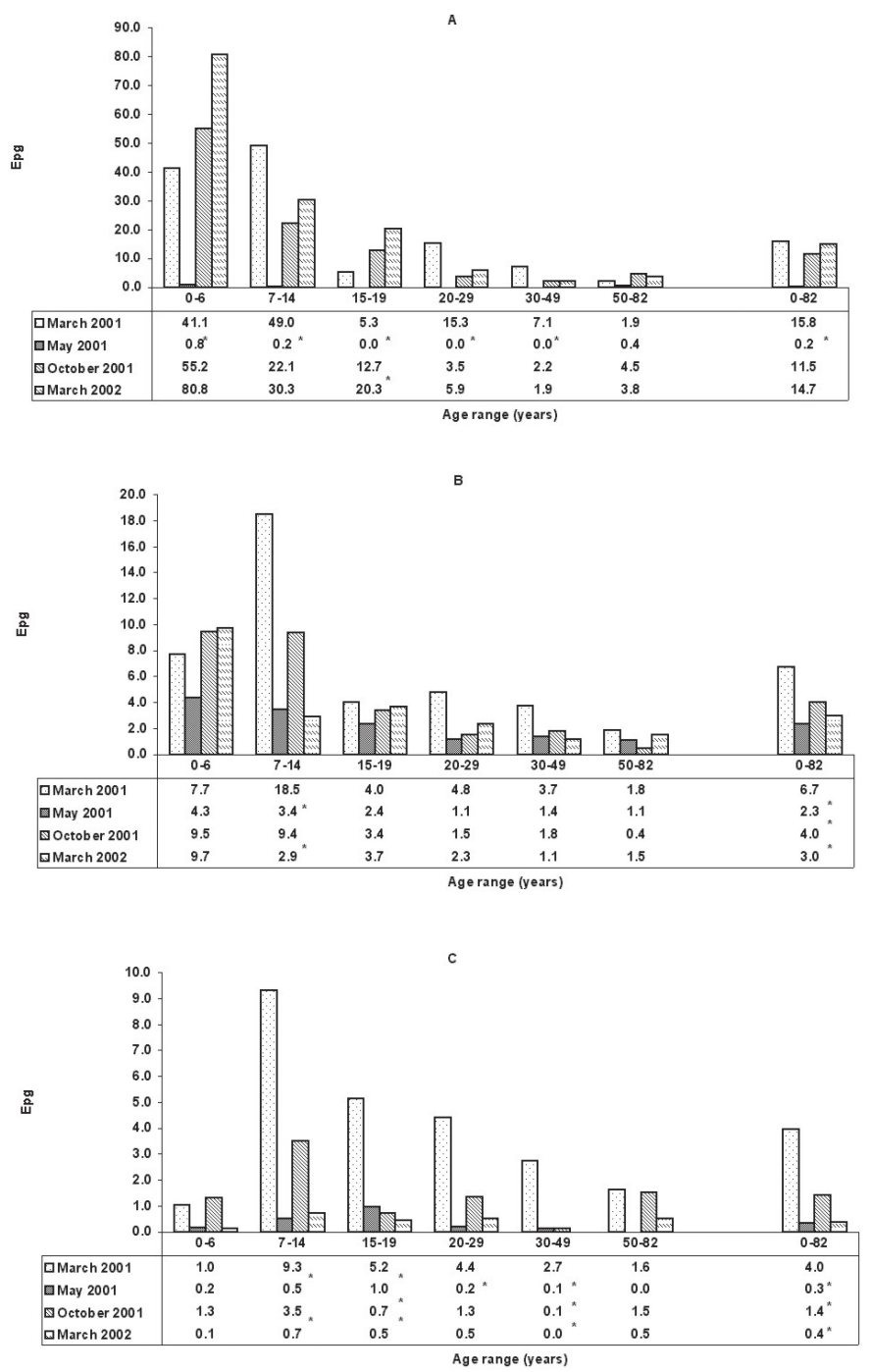

Fig. 3 - Intensity of infection (epg) by Ascaris lumbricoides (3A), Trichuris trichiura (3B) and hookworms $(3 \mathrm{C})$ in the follow-up cohort from Covas, by age range, prior to (March $2001)$ and at subsequent surveys after treatment. The asterisks indicate significant differences $(\mathrm{p}<0.05)$ between the pre-treatment survey and each subsequent survey. 


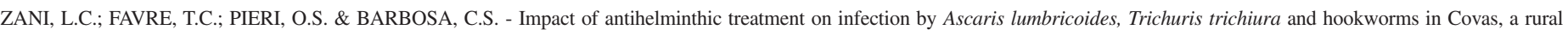
community of Pernambuco, Brazil. Rev. Inst. Med. trop. S. Paulo, 46(2):63-71, 2004.

Table 2

Egg negative rates (\%) among subjects positive for Ascaris lumbricoides, Trichuris trichiura and hookworms in the infected cohort (n = 119) from Covas one month after treatment (May 2001) with either mebendazole or albendazole

\begin{tabular}{|c|c|c|c|c|c|c|c|c|c|}
\hline \multirow[b]{2}{*}{ Drugs } & \multicolumn{3}{|c|}{ A. lumbricoides } & \multicolumn{3}{|c|}{ T. trichiura } & \multicolumn{3}{|c|}{ Hookworms } \\
\hline & $\begin{array}{c}\text { Number } \\
\text { tested } \\
\text { positive }\end{array}$ & $\begin{array}{l}\text { Number } \\
\text { becoming } \\
\text { negative }\end{array}$ & $\begin{array}{c}\text { Egg } \\
\text { negative } \\
\text { rate }(\%)\end{array}$ & $\begin{array}{c}\text { Number } \\
\text { tested } \\
\text { positive }\end{array}$ & $\begin{array}{c}\text { Number } \\
\text { becoming } \\
\text { negative }\end{array}$ & $\begin{array}{c}\text { Egg } \\
\text { negative } \\
\text { rate }(\%)\end{array}$ & $\begin{array}{c}\text { Number } \\
\text { tested } \\
\text { positive }\end{array}$ & $\begin{array}{l}\text { Number } \\
\text { becoming } \\
\text { negative }\end{array}$ & $\begin{array}{c}\text { Egg } \\
\text { negative } \\
\text { rate }(\%)\end{array}$ \\
\hline Mebendazole & 41 & 37 & 90.2 & 39 & 15 & 38.5 & 41 & 24 & 58.5 \\
\hline Albendazole & 42 & 41 & 97.6 & 38 & 20 & 52.6 & 41 & 32 & 78.0 \\
\hline Mebendazole + Albendazole & 83 & 78 & 94.0 & 77 & 35 & 45.5 & 82 & 56 & 68.3 \\
\hline
\end{tabular}

variables allowed for the formation of two statistically homogeneous groups for geohelminthiases in March 2001. Thus, the two groups did not differ significantly in relation to prevalence (Chi-square test) and intensity of infection ( $t$-test) either by $A$. lumbricoides $\left(\chi^{2}=0.076, \mathrm{df}=\right.$ $1, \mathrm{p}>0.05 ; \mathrm{t}=0.330, \mathrm{df}=103, \mathrm{p}>0.05)$, by T. trichiura $\left(\chi^{2}=0.005, \mathrm{df}\right.$ $=1, \mathrm{p}>0.05 ; \mathrm{t}=0.973, \mathrm{df}=103, \mathrm{p}>0.05)$ or by hookworms $\left(\chi^{2}=\right.$ $0.485, \mathrm{df}=1, \mathrm{p}>0.05 ; \mathrm{t}=1.186, \mathrm{df}=103, \mathrm{p}>0.05)$.

There was no significant difference $(\mathrm{p}>0.05)$ in the egg-negative rates among subjects treated with either one drug or the other (Table 2). The proportion of subjects becoming negative after treatment, considering the two drugs jointly, was significant $(\mathrm{p}<0.05)$ for $A$. lumbricoides and for hookworms, but not for T. trichiura. The egg-negative rate of those infected by A. lumbricoides was significantly higher $(\mathrm{p}<0.05)$ than that of those infected by $T$. trichiura or hookworms; on the other hand, it was significantly higher $(\mathrm{p}<0.05)$ among those infected by hookworms as compared to those infected by T. trichiura.

Out of 60 subjects tested positive for A. lumbricoides detected by Kato-Katz, $58(96.7 \%)$ became negative after treatment. Of the two subjects remaining positive, only one reduced the egg count. Only 29 (41.4\%) out of 70 that tested positive for T. trichiura, became negative with the treatment. Therefore, 41 subjects remained positive after treatment. Nevertheless, the Sign test detected 40 discrepancies between egg count (epg) before and after treatment, thus indicating that there was a significant reduction in the egg counts of T. trichiura even among people who remained positive after treatment. Out of 49 infected by hookworms, 44 (89.8\%) became negative. Egg counts fell in four out of five subjects that remained positive one month after treatment. Two of these were substantially reduced: $99.9 \%$ (from 6,336 epg to $6 \mathrm{epg}$ ) and $92.3 \%$ (from 636 epg to $48 \mathrm{epg}$ ); while the reduction in the other two, was not so marked: $27.3 \%$ (from $132 \mathrm{epg}$ to $96 \mathrm{epg}$ ) and $20.7 \%$ (from 174 epg to 138 epg).

All 119 participants in the infected cohort were positive in March 2001 for at least one of the three geohelminths (Table 3). One month after treatment, $52.9 \%$ became negative, however, the remaining subjects continued in one of the three infection categories. Cases of single infection by $A$. lumbricoides and hookworms were reduced after treatment, whereas those by $T$. trichiura increased almost three fold. Cases of double infection in the combinations A. lumbricoides + hookworms and A. lumbricoides $+T$. trichiura were reduced after treatment, reaching zero in the first combination. As for cases of double infection by $T$. trichiura + hookworms, there was a slight increase. Cases of triple infection were substantially reduced with treatment. Increases of single infection percentages after treatment, mainly by $T$. trichiura, reflect a shift of cases belonging to the categories of double infection or triple infection before the treatment. Indeed, out of 47 subjects who initially had triple infection, $29(61.7 \%)$ remained double-infected $(\mathrm{n}=17)$ or single-infected $(\mathrm{n}=$ 12) by $T$. trichiura after treatment. Out of 21 subjects who initially had double infection involving combinations with T. trichiura, 8 (38.1\%) became single-infected by that geohelminth. This result indicates that the treatment with either drug produced a reduction in cases of multiple infections and that most cases remaining positive were associated with T. trichiura.

Reinfection rates for A. lumbricoides $\left(\chi^{2}=20.48, \mathrm{df}=1, \mathrm{p}<0.05\right)$, T. trichiura $\left(\chi^{2}=9.00, \mathrm{df}=1, \mathrm{p}<0.05\right)$ and hookworms $\left(\chi^{2}=10.50\right.$, df $=1, \mathrm{p}<0.05)$ were significantly higher $(\mathrm{p}<0.05)$ during the first five months (June to October 2001) following the first post-treatment survey than during the period of November 2001 to March 2002 (Table 4).

Social, demographic, sanitary and behavioral variables related to geohelminthiases: A comparative analysis of living conditions before (December 2000) and after (December 2001) antihelminthic treatment showed that there were no significant changes in environmental, sanitary and behavioral variables considered relevant to the maintenance of transmission of geohelminthiases during the interval between administration of the two home questionnaires (Table 5).

\section{Table 3}

Single and multiple infection by Ascaris lumbricoides (Asc), Trichuris trichiura (Tric) and hookworms (Hook) in the infected cohort ( $\mathrm{n}=$ 119) from Covas prior to (March 2001) and one month after treatment (May 2001) with either mebendazole or albendazole. Prevalences (\%) are in parentheses

\begin{tabular}{lccc}
\hline Categories & Geohelminth & \multicolumn{2}{c}{ Number of positive cases } \\
\cline { 3 - 4 } of infection & & March/2001 & May/2001 \\
\hline Single infection & Asc & $13(10.9 \%)$ & $2(3.6 \%)$ \\
& Tric & $9(7.7 \%)$ & $26(46.4 \%)$ \\
\multirow{2}{*}{ Double infection } & Hook & $22(18.5 \%)$ & $13(23.2 \%)$ \\
& Asc+Hook & $7(5.9 \%)$ & $0(0.0 \%)$ \\
& Asc+Tric & $14(11.8 \%)$ & $2(3.6 \%)$ \\
Triple infection & Aric+Hook & $7(5.9 \%)$ & $11(19.6 \%)$ \\
Total of positives & & $47(39.5 \%)$ & $2(3.6 \%)$ \\
\hline
\end{tabular}




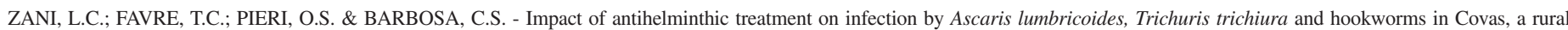
community of Pernambuco, Brazil. Rev. Inst. Med. trop. S. Paulo, 46(2):63-71, 2004.

Table 4

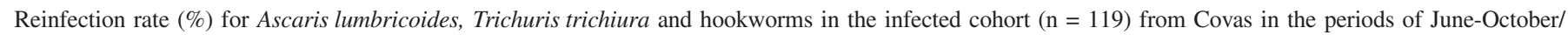
2001 and November/2001-March/2002

\begin{tabular}{|c|c|c|c|c|c|c|c|c|c|}
\hline \multirow[t]{2}{*}{ Periods } & \multicolumn{3}{|c|}{ A. lumbricoides } & \multicolumn{3}{|c|}{ T. trichiura } & \multicolumn{3}{|c|}{ Hookworms } \\
\hline & $\begin{array}{c}\text { Number } \\
\text { becoming } \\
\text { negative }\end{array}$ & $\begin{array}{l}\text { Number } \\
\text { reinfected }\end{array}$ & $\begin{array}{l}\text { Reinfection } \\
\text { rate }(\%)\end{array}$ & $\begin{array}{c}\text { Number } \\
\text { becoming } \\
\text { negative }\end{array}$ & $\begin{array}{l}\text { Number } \\
\text { reinfected }\end{array}$ & $\begin{array}{l}\text { Reinfection } \\
\text { rate }(\%)\end{array}$ & $\begin{array}{c}\text { Number } \\
\text { becoming } \\
\text { negative }\end{array}$ & $\begin{array}{l}\text { Number } \\
\text { reinfected }\end{array}$ & $\begin{array}{l}\text { Reinfection } \\
\text { rate }(\%)\end{array}$ \\
\hline $\begin{array}{l}\text { June/2001 to } \\
\text { October/2001 }\end{array}$ & 78 & 41 & 52.6 & 56 & 21 & 37.5 & 35 & 14 & 40.0 \\
\hline $\begin{array}{l}\text { November/2001 to } \\
\text { March/2002 }\end{array}$ & 78 & 9 & 11.5 & 56 & 0 & 0.0 & 35 & 2 & 5.7 \\
\hline
\end{tabular}

Table 5

Social, demographic, sanitary and behavioral variables related to geohelminth infection in Covas, based on a questionnaire applied prior to (December 2000) and after treatment (December 2001)

\begin{tabular}{lcc}
\hline Variables & $\begin{array}{c}\text { December } \\
2000\end{array}$ & $\begin{array}{c}\text { December } \\
2001\end{array}$ \\
\hline $\begin{array}{l}\text { Population } \\
\text { Houses }\end{array}$ & 250 & 201 \\
Families with income below & 44 \\
one minimum wage & $54.5 \%$ & $78.9 \%$ \\
Households with qualified workers & $13.6 \%$ & $14.7 \%$ \\
Illiterate over 7 years of age & $24.9 \%$ & $27.9 \%$ \\
Residents reporting soil-related & & \\
behaviour & $77.9 \%$ & $76.6 \%$ \\
Residents without habit of & & \\
hand/food washing & $92.8 \%$ & $94.5 \%$ \\
Residents reporting nailbiting behavior & $18.1 \%$ & $25.9 \%$ \\
Houses without sanitary installations & $38.6 \%$ & $55.3 \%$ \\
Houses without filtered drinking water & $36.4 \%$ & $31.6 \%$ \\
Houses without adequate faecal disposal & $45.5 \%$ & $57.9 \%$ \\
Houses with domestic animals & $79.5 \%$ & $84.2 \%$ \\
\hline
\end{tabular}

\section{DISCUSSION}

According to COLLEY ${ }^{7}$ the main goal of geohelminthiasis control is the reduction of parasite load, which involves efforts to reduce transmission and/or morbidity. In the area where the present study was carried out, only one treatment was capable of maintaining prevalence below pre-control levels over at least one year, although there was no change with respect to poor socioeconomic and environmental conditions, nor any change in behavioral patterns favoring infection. The treatment also reduced egg counts substantially, even among the subjects who remained positive.

The results on prevalence of infection and of cumulative infection corroborate data found in the literature with respect to the three helminths, under no-treatment conditions ${ }^{10}$, as well as under treatment ${ }^{1}$. Therefore, infection by $T$. trichiura and hookworms were kept below pre-treatment levels, whereas infection by A. lumbricoides returned to the initial level within 11 months. Increase in prevalence of $A$. lumbricoides in the follow- up cohort reinforces the evidence that, in addition to the risk behavior of the host, this geohelminth has characteristics that greatly increase the chances of reinfection: great fertility, high resistance of embryonated eggs under adverse conditions and ample dispersion in the environment, including inside the houses. Infection by T. trichiura and hookworms apparently needs more time to return to pre-treatment leve ${ }^{16}$ since both geohelminths have less resistant eggs compared to those of $A$. lumbricoides, their females lay fewer eggs, in addition to the fact that the infecting larvae of hookworms are more susceptible to desiccation.

Prevalence of A. lumbricoides had no substantial variation between the various age groups, neither before nor after treatment, which may be due to similar conditions of exposure to the helminth by most residents of the village. These data are in accordance with those obtained in some areas $^{5}$, where prevalence of this helminth remained relatively high in all age groups; however, they contrast with data from other areas, where prevalence reached its peak in the 5-15 year-old group ${ }^{5,28}$. As for intensity of infection by age group, our results agree with those from the literature ${ }^{9,31}$, as the egg counts of $A$. lumbricoides are concentrated in groups of younger individuals, and tend to decline in adulthood. This pattern persists even after treatment.

Results on prevalence of hookworms by age group agree with those reported by LABIANO-ABELLO et al. ${ }^{19}$ who found the highest values among those aged 5-29 years. As for intensity of infection, results point to a larger aggregation in the 7-14 year-old group, similar to data by ANDERSON $^{2}$.

Results on prevalence of $T$. trichiura in different age groups agree with those reported by BUNDY et al. ${ }^{5}$ who indicated a peak between the ages of 5 and 15 years, but contrast with those of SMITH et al. ${ }^{28}$ who did not detect any decline in adulthood. This contrast is probably due differences in exposure risks between the study areas. As for intensity of infection, our results agree with those by UPATHAM et al. ${ }^{31}$ who reported a larger concentration of egg counts in the 5-10 year-old group. Decline in intensity of infection among older subjects observed in the present work is confirmed by DRAKE \& BUNDY ${ }^{9}$ and STEPHENSON et al. ${ }^{30}$.

The fact that intensity of infection by the three geohelminths is concentrated in certain age groups may be due not only to age characteristics but also to the aggregated distribution of these worms, since most hosts carry few worms, and higher egg counts are concentrated in a minority of individuals. According to HALL et al. ${ }^{14}$, this aggregated 
distribution may be due to differences in the host's behavior, to irregular distribution of infecting stages in the environment or to differences in the host's ability to generate an adequate immunological response.

Results on prevalence in relation to infection category show that in March 2001 the village of Covas corresponded to category II (high prevalence and low intensity) according to the classification by MONTRESOR et al. ${ }^{21}$. For communities in that category, annual targeted treatment is recommended; the groups identified for treatment are women of childbearing age, as well as pre-school and school-age children.

However, it is likely that selective treatment, that is, treatment administered individually based on the diagnosis of current infection, would be more suitable for the village of Covas than targeted treatment. Thus, children over school age, male adults and women above the reproductive phase were also infected by geohelminths, acting as important sources of contamination of the environment. If the treatment administered in March 2001 had been targeted as suggested by MONTRESOR et al. ${ }^{21}$, only 98 subjects (64 children and 34 women) would have been medicated, still leaving 40 subjects with geohelminth eggs in the feces. On the other hand, with selective treatment, medication would cover, as actually occurred, all 138 positive-tested subjects.

Results on egg-negative rate agree with those in the literature, that report high rates (above $97.0 \%$ ) for $A$. lumbricoides ${ }^{17}$, medium rates (around $60.0 \%$ ) for hookworms and low rates (around 38.0\%) for T. trichiura ${ }^{3}$. The low egg-negative rates obtained for $T$. trichiura may be justified by the differing locations of the adult worms in the intestine. Therefore, in $T$. trichiura, only the posterior portion of the worm (essential for defecation, copulation and oviposition) is free in the intestinal lumen, with the anterior portion being inserted in the intestinal epithelium. As regards $A$. lumbricoides and hookworms, the whole body of the worm remains in the intestinal lumen. This slight difference in location of the adult worm may also imply differentiated exposure to antihelminthic drugs that act in the intestinal lumen. Consequently, studies aiming at the formulation of more effective drugs are necessary, particularly for T. trichiura.

The low egg-negative rates obtained for T. trichiura are compensated by a significant reduction in the egg counts, a fact also reported by other authors ${ }^{17}$. According to NORHAYATI et al..$^{23}$, drugs are more effective in the reduction of the female fertility of $T$. trichiura than in the removal of the adult worm from the host; as for A. lumbricoides and hookworms, the major effect of the drug is to promote parasitological cure.

As regards the egg-negative rate in relation to the drug that was administered, the results of this study agree with those reported by RAHMAN $^{25}$ who showed similar rates, above $90 \%$, in relation to mebendazole and albendazole for A. lumbricoides. As far as hookworms are concerned, JONGSKSUNTIGUL et $a 1 .{ }^{17}$, RAHMAN ${ }^{25}$ and MUCHIRI et al. ${ }^{22}$ found higher egg-negative rates with albendazole (57\% - $92 \%$ ) than with mebendazole $(22 \%$ - 50\%). These results are in contrast with the ones obtained in the present study, where rates were similar (78.0\% and $59.0 \%$, respectively) for both drugs. For T. trichiura, RAHMAN $^{25}$ obtained lower egg-negative rates for albendazole (12\% $38 \%)$ than for mebendazole $(50 \%-89 \%)$. These contrasting results indicate that further studies under real field conditions are necessary to evaluate the efficacy of these drugs under varying eco-epidemiological situations.
Albendazole and mebendazole proved to be equally effective as they produced satisfactory rates for both egg-negative rate and egg-count reduction. Nevertheless, albendazole may be considered the ideal drug under the conditions of the present study due to the lower cost-benefit ratio. Albendazole is administered in a single dose, thus it offers lower operational costs to guarantee total treatment compliance. Treatment with mebendazole, on the other hand, requires three split doses. The advantage in using albendazole became even more evident because treatment was carried out at the community level, and not in the school environment, where its operationalization would have been much easier. It is interesting to point out that the area of the present study is also endemic for schistosomiasis, which reinforces the recommendation by the WHO to promote the joint control of this infection and geohelminthiases ${ }^{36}$. Such integration can be justified not only by logistic reasons but also by the fact that praziquantel, a drug used to treat carriers of Schistosoma mansoni, is also effective against hookworms. Therefore, according to UTZINZER et al. ${ }^{32}$, combined therapy of praziquantel and albendazole is more effective in reducing prevalence and egg counts of hookworms than a single administration of albendazole.

Results on single infection prior to treatment agree with those found by UPATHAM et al. ${ }^{31}$ as they report higher prevalence for hookworms and lower prevalence for A. lumbricoides, although percentage values varied. As regards double infection, the present results agree with the findings by DRAKE \& BUNDY $^{9}$, who showed highest prevalence in the combination A. lumbricoides $+T$. trichiura. The present results on triple infection are similar to those by UPATHAM et $a l .{ }^{31}$, who reported prevalence around $30 \%$.

As regards multiple infections after treatment, it is worth mentioning that although changes in the status of infection (from triple infection to double or single infection) were not followed by a significant decline in prevalence for each geohelminth, they might have had an important effect on morbidity. In fact, DRAKE \& BUNDY ${ }^{9}$ emphasized that the risk of morbidity caused by only one species is related to intensity of infection. Other authors also mention that individuals with multiple infections tend to display higher intensity of infection than that expected for each infection separately ${ }^{4}$.

Results on reinfection agree with data reported by NORHAYATI $e t$ $a l .{ }^{23}$, who observed the highest rates in A. lumbricoides and the lowest in T. trichiura. The fact that, in the present study, reinfection was significantly higher in the months of June to October 2001 than in the months of November 2001 to March 2002 may be explained by rainfall variations, as the rainy season favors the transmission of geohelminthiases ${ }^{1}$. Actually, the monthly rainfall between June and October 2001 was $680 \mathrm{~mm}$, whereas, between November 2001 and March 2002, it was merely $360 \mathrm{~mm}$.

As far as the results of the present study are concerned, the following recommendations can be offered for the transmission control of these geohelminths: (a) the treatment must be selective and with albendazole, every six months (preferably in March and September), due to the rapid aggravation of the infection, especially by $A$. lumbricoides, taking into account seasonal transmission conditions; (b) drug treatment must be complemented with prophylactic measures such as improved sanitation and programs of information, education and communication; and (c) the treatment should be on a yearly basis (March) as reinfection rates fall. 


\section{RESUMO}

\section{Impacto do tratamento antihelmíntico sobre a infecção por Ascaris lumbricoides, Trichuris trichiura e ancilostomídeos na população rural de Covas, Pernambuco, Brasil}

Este trabalho avalia o impacto do tratamento antihelmíntico sobre a infecção por A. lumbricoides $(\mathrm{Al})$, T. trichiura $(\mathrm{Tt})$ e ancilostomídeos (Anc) na população de Covas, Pernambuco. Durante março/2001 e março/2002, quatro inquéritos parasitológicos foram realizados. Em cada um foram coletados dois exames de fezes por morador. O diagnóstico foi feito pelos métodos de Kato-Katz e Hoffmann. Em abril/01, os indivíduos positivos foram separados em dois grupos para tratamento com albendazol $(n=62)$ ou mebendazol $(n=57)$. As proporções de indivíduos positivos reduziram-se significativamente um mês póstratamento: $\mathrm{Al}$ (de $47,7 \%$ para $6,6 \%$ ), Tt (de $45,7 \%$ para $31,8 \%$ ) e Anc (de $47,7 \%$ para $24,5 \%$ ); permanecendo abaixo do nível inicial um ano pós-tratamento. Os casos de monoinfecção, exceto os por Tt, e infecções múltiplas reduziram-se após o tratamento. A negativação foi significativa para $\mathrm{Al}(94,0 \%)$, Anc $(68,3 \%)$, mas não para $\mathrm{Tt}(45,5 \%)$ e foi maior para Al. A negativação não diferiu significativamente entre os tratados com mebendazol ou albendazol. A intensidade da infecção reduziu-se significativamente nos indivíduos que permaneceram positivos para Tt. Recomenda-se que o tratamento seja seletivo, administrado anualmente, de preferência com albendazole, devido ao seu custo-benefício.

\section{ACKNOWLEDGEMENTS}

The authors are grateful to the technical staff of the Reference Laboratory for Schistosomiasis Diagnosis at the Department of Parasitology, Aggeu Magalhães Research Centre for their support in the parasitological surveys.

\section{REFERENCES}

1. ALBONICO, M.; STOLZFUS, R.J.; SAVIOLI, L. et al. - A controlled evaluation of two school-based antihelminthic chemotherapy regimens on intensity of intestinal helminth infections. Int. J. Epidem., 28: 591-596, 1999.

2. ANDERSON, R. M. - The population dynamics and epidemiology of intestinal nematode infections. Trans. roy. Soc. trop. Med. Hyg., 80: 686-696, 1986.

3. BENNETT, A. \& GUYATT, H. - Reducing intestinal nematode infection: efficacy of albendazole and mebendazole. Parasit. today, 16: 71-74, 2000.

4. BROOKER, S.; MIGUEL, E.; MOULIN, S. et al. - Epidemiology of single and multiple species of helminth infections among school children in Busia District, Kenya. East Afr. med. J., 77: 157-161, 2000.

5. BUNDY, D.A.P.; COOPER, E.S.; THOMPSON, D.E.; DIDIER, J.M. \& SIMMONS, I. Epidemiology and population dynamics of Ascaris lumbricoides and Trichuris trichiura infection in the same community. Trans. roy. Soc. trop. Med. Hyg., 81: 987-993, 1987.

6. BUNDY, D.A.P.; CHANDIWANA, S.K.; HOMEIDA, M.M.A.; YOON, S. \& MOTT, K.E. - The epidemiological implications of a multiple-infection approach to the control of human helminth infections. Trans. roy. Soc. trop. Med. Hyg., 85: 274-276, 1991.

7. COLLEY, D.G. - Parasitics diseases: opportunities and challenges in the 21 st century. Mem. Inst. Oswaldo Cruz, 95 (suppl. 1): 779-787, 2000.

8. CROMPTON, D.W. - How much human helminthiasis is there in the world? J. Parasit., 85: 397-403, 1999.
9. DRAKE, L.J. \& BUNDY, D.A.P. - Multiple helminth infection in children: impact and control. Parasitology, 122: S73-S81, 2001.

10. EVE, E.; FERRAZ, E. \& THATCHER, V.E. - Parasitic infections in villagers from three districts of the Brazilian Amazon. Ann. trop. Med. Parasit., 92: 79-87, 1998.

11. FAVRE, T.C.; PIERI, O.S.; BARBOSA, C.S. \& BECK, L. - Avaliação das ações de controle da esquistossomose implementadas entre 1977 e 1996 na área endêmica de Pernambuco, Brasil. Rev. Soc. bras. Med. trop., 34: 569-576, 2001.

12. FERREIRA, C.S.; FERREIRA, M.U. \& NOGUEIRA, M.R. - The prevalence of infection by intestinal parasites in an urban slum in São Paulo, Brazil. J. trop. Med. Hyg., 97: 121-127, 1994.

13. FERREIRA, M.U.; FERREIRA, C.S. \& MONTEIRO, C.A. - Tendência secular das parasitoses intestinais na infância na cidade de São Paulo (1984 - 1996). Rev. Saúde públ. (S. Paulo), 34 (suppl. 6): 73-82, 2000.

14. HALL, A.; ANWAR, K.S. \& TOMKINS, A.M. - Intensity of reinfection with Ascaris lumbricoides and its implications for parasite control. Lancet, 339: 1253-1257, 1992.

15. HOFFMANN, W.A.; PONS, J.A. \& JANER, S.L. - The sedimentation concentration method in schistosomiasis mansoni. J. publ. Hlth., 9: 283-291, 1934.

16. IDRIS, M.A.; SHABAN, M.A.A. \& FATAHALLAH, M. - Effective control of hookworm infection in school children from Dhofar, Sultanate of Oman: a four-year experience with albendazole mass chemotherapy. Acta trop. (Basel), 80: 139-143, 2001.

17. JONGSUKSUNTIGUL, P.; JERADIT, C.; POMPATTANAKUL, S. \& CHARANASRI, U. - A comparative study on the efficacy of albendazole and mebendazole in the treatment of ascariasis, hookworm infection and trichuriasis. Southeast Asian J. trop. Med. publ. HIth., 24: 724-729, 1993.

18. KATZ, N.; CHAVES, A. \& PELLEGRINO, J. - A simple device for quantitative stool thick-smear technique in schistosomiasis mansoni. Rev. Inst. Med. trop. S. Paulo, 14: 397-400, 1972.

19. LABIANO-ABELLO, N.; CANESE, J.; VELÁSQUEZ, M.E. et al. - Epidemiology of hookworm infection in Itagua, Paraguay: a cross sectional study. Mem. Inst. Oswaldo Cruz, 94: 583-586, 1999.

20. MONTEIRO, C.A.; CHIEFFI, P.P.; BENÍCIO, M.H.A. et al. - Estudo das condições de saúde das crianças do município de São Paulo (Brasil), 1984/1985. VII. Parasitoses intestinais. Rev. Saúde públ. (S. Paulo), 22 (suppl. 1): 8-15, 1988.

21. MONTRESOR, A.; CROMPTON, D.W.T.; BUNDY, D.A.P.; HALL, A. \& SAVIOLLI, L. - Guidelines for the evaluation of soil-transmitted helminthiasis and schistosomiasis at community level: a guide for managers of control programmes. Geneva, 1998. (WHO/CTD/SIP/98.1)

22. MUCHIRI, M.; THIONGO, F.W.; MAGNUNSSEN, P. \& OUMA, J. - Comparative study of different albendazole and mebendazole regimens for the treatment of intestinal infections in schoolchildren Usigu division, Western Kenya. J. Parasit., 87: 413418,2001

23. NORHAYATI, M.; OOTHUMAN, P.; AZIZI, O. \& FATMAH, M.S. - Efficacy of single dose albendazole on the prevalence and intensity of infection of soil-transmitted helminths in Orang Asli children in Malaysia. Southeast Asian J. trop. Med. publ. Hlth., 28: 563-569, 1997.

24. PELLÓN, A.B. \& TEIXEIRA, I. - Distribuição da esquistossomose mansônica no Brasil. Rio de Janeiro, Divisão de Organização Sanitária, 1950.

25. RAHMAN, W.A. - Comparative trials using albendazole and mebendazole in the treatment of soil-transmitted helminths in schoolchildren on Penang, Malaysia. Southeast Asian J. trop. Med. publ. Hlth., 27: 765-767, 1996.

26. SIEGEL, S. - Nonparametric statistics for the behavioral sciences. Tokyo, Mc GrawHill International Book Company, 1956. 

community of Pernambuco, Brazil. Rev. Inst. Med. trop. S. Paulo, 46(2):63-71, 2004.

27. SIGULEM, D.M.; TUDISCO, E.S.; PAIVA, E.R. \& GUERRA, C.C. - Anemia nutricional e parasitose intestinal em menores de cinco anos. Rev. paul. Med., 103: 308-312, 1985.

28. SMITH, H.M.; DEKAMINSKY, R.G.; NIWAS, S.; SOTO, R.J. \& JOLLY, P.E. Prevalence and intensity of infections of Ascaris lumbricoides and Trichuris trichiura and associated socio-demographic variables in four rural Honduran communities. Mem. Inst. Oswaldo Cruz, 96: 303-314, 2001.

29. SOKAL, R.S. \& ROHFL, F.J. - Biometry: the principles and practice of statistics in biological research. New York, Freeman, 1995.

30. STEPHENSON, L.S.; HOLLAND, C.V. \& COOPER, E.S. - The public health significance of Trichuris trichiura. Parasitology, 121(suppl.): S73-S95, 2000.

31. UPATHAM, E.S.; VIYANANT, V.; BROCKEMAN, W.Y. et al. - Prevalence, incidence, intensity and associated morbidity of intestinal helminths in South Thailand. Int. J. Parasit., 19: 217-228, 1989.

32. UTZINGER, J.; VOUNATSOU, P.; NGORAN, E.K.N.; TANNER, M. \& BOOTH, M. Reduction in the prevalence and intensity of hookworm infections after praziquantel treatment for schistosomiasis infection. Int. J. Parasit., 32: 759-765, 2002.
33. VINHA, C. - Incidência, no Brasil, de helmintos transmitidos pelo solo. Rotina coproscópica do ex-Departamento Nacional de Endemias Rurais. Rev. bras. Malar. 5: $3-15,1971$.

34. WALDMAN, E.A. \& CHIEFFI, P.P. - Enteroparasitoses no Estado de São Paulo: questão de saúde pública. Rev. Inst. Adolfo Lutz, 49: 93-99, 1989.

35. WORLD HEALTH ORGANIZATION - Report of the WHO Informal Consultation on the use of chemotherapy for the control of morbidity due to soil-transmitted Nematodes in humans. Geneva, 1986.

36. WORLD HEALTH ORGANIZATION - Report of the WHO Informal Consultation on schistosomiasis control. Geneva, 1999. (WHO/CDS/CPC/SIP/99.2).

37. ZANI, L.C. - Impacto do tratamento antihelmíntico sobre as geohelmintoses em uma comunidade rural de Pernambuco: um estudo longitudinal. Rio de Janeiro, 2002. (Dissertação de Mestrado - Instituto Oswaldo Cruz).

Received: 6 March 2003

Accepted: 4 March 2004 